\title{
Innovate Innovation Management
}

Die Größe eines Wortes stellt die relative Häufigkeit in den Beiträgen des Heft-Schwerpunktes dar.

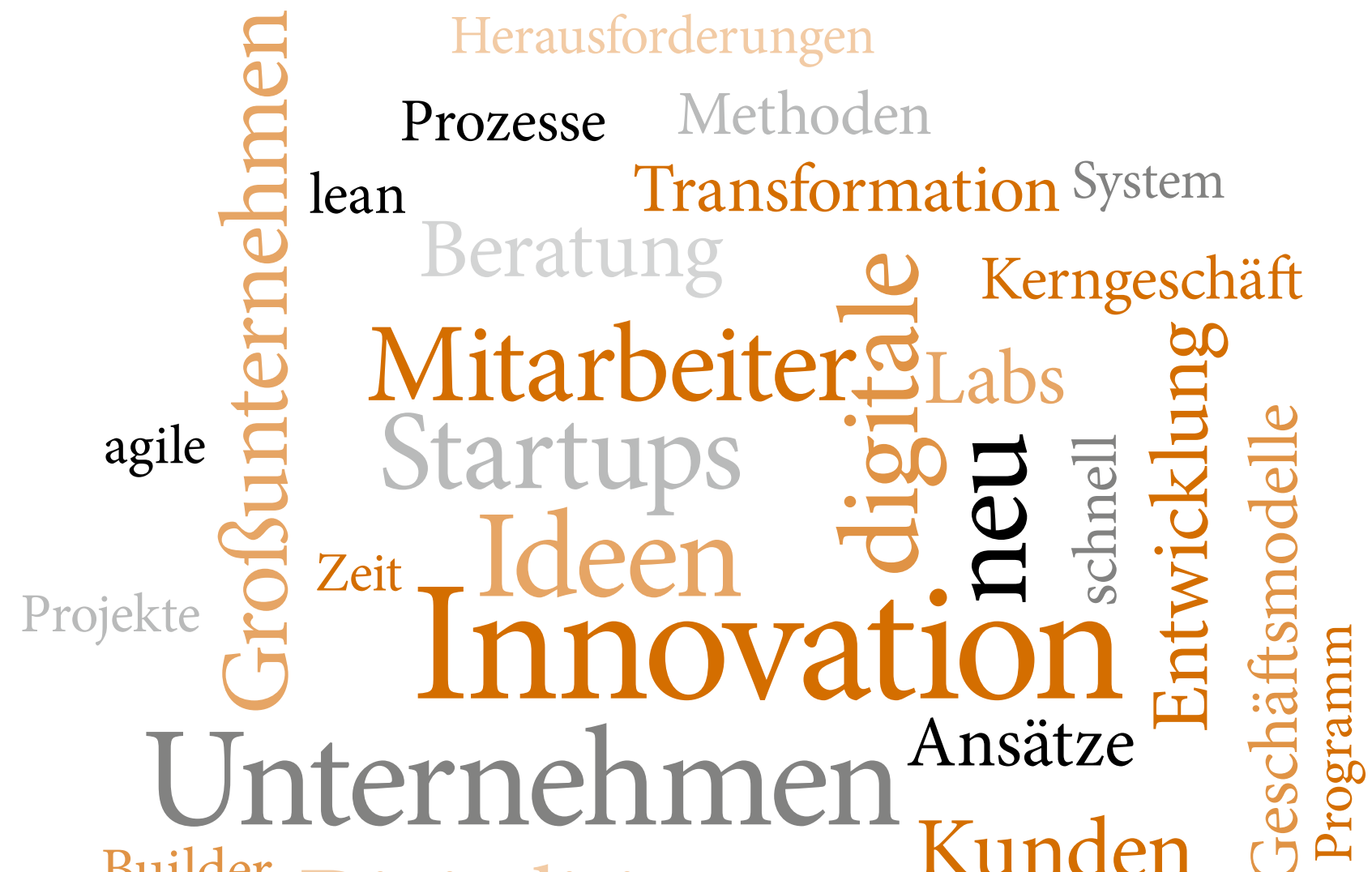

Ressourcen

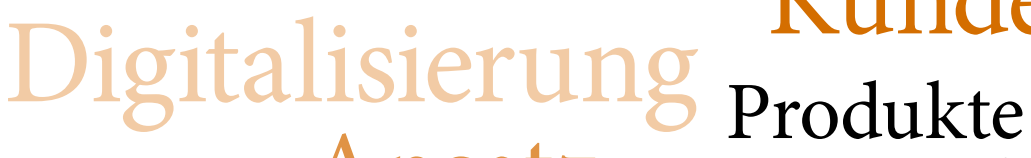

Technologien

entwickeln Firmen

Tabelle testen Zusammenarbeit

Innovationsmanagement

Innovationsdesign 